\title{
Basic Principles (Indicators) for Assessing the Technical and Economic Potential of Developing Arctic Offshore Oil and Gas Fields
}

\author{
Gennady Stroykov ${ }^{1, *(D)}$, Yurii N. Vasilev ${ }^{1}$ (D) and Oleg V. Zhukov ${ }^{2}$ \\ 1 Department of Economics, Organisation and Management, Saint-Petersburg Mining University, 21 Line, 2, \\ 199106 St. Petersburg, Russia; yur_vas1@mail.ru \\ 2 Luzin Institute for Economic Studies of the Kola Science Centre, Russian Academy of Sciences (IES KSC RAS), \\ 24a, Fersmana Str., 184209 Apatity, Russia; jukov@yandex.com \\ * Correspondence: g.a.stroykov@mail.ru; Tel.: +7-90-5209-7516
}

Citation: Stroykov, G.; Vasilev, Y.N.; Zhukov, O.V. Basic Principles (Indicators) for Assessing the Technical and Economic Potential of Developing Arctic Offshore Oil and Gas Fields. J. Mar. Sci. Eng. 2021, 9, 1400. https://doi.org/10.3390/ jmse9121400

Academic Editor: Dejan Brkić

Received: 15 November 2021

Accepted: 6 December 2021

Published: 8 December 2021

Publisher's Note: MDPI stays neutral with regard to jurisdictional claims in published maps and institutional affiliations.

Copyright: (C) 2021 by the authors Licensee MDPI, Basel, Switzerland. This article is an open access article distributed under the terms and conditions of the Creative Commons Attribution (CC BY) license (https:/ / creativecommons.org/licenses/by/ $4.0 /)$.

\begin{abstract}
Sustainable development of the Arctic is the main priority of the state policy regarding regional development of the Russian Federation. The study of the Arctic zone of the Russian Federation for the formation of principles, methods and strategies, as well as organizational and economic mechanisms for its sustainable development is topical at present. This article deals with one of the strategic decision-making tools used in the process of implementing the development program for the Russian Arctic, namely, the assessment of the technical and economic potential of the Arctic fields. The purpose of this assessment is to rank the fields according to the priority of their commissioning for a more optimal distribution of costs in the development of Arctic resources. This paper presents the results and methodology of technical and economic potential estimation in general, and the potential of the Arctic oil and gas fields in particular. An analysis of the conceptual apparatus in the field of the evaluation of various types of potential is carried out. The methodology for assessing the technical and economic potential of a field are investigated. The problems arising in the process of such an assessment are revealed. Recommendations for improving the methodology of assessing the technical and economic potential of oil and gas fields in the Arctic are given. The necessity of expanding the list of indicators for assessing the technical and economic potential of these fields, taking into account current trends, has been noted. A list of 10 technical and 26 economic indicators to assess the technical and economic potential of the development of offshore Arctic fields is proposed.
\end{abstract}

Keywords: arctic; strategic management; hydrocarbon resources; technical and economic potential; offshore oil and gas fields; sustainable development; comparative analysis

\section{Introduction}

The prospects for the development of the world's Arctic zone are determined by its potential. According to the National Petroleum Council, up to a quarter of the world's undiscovered hydrocarbon reserves are in the Arctic, with a significant portion of the Arctic's hydrocarbon potential coming from the Arctic seas. Currently, the Arctic is a place where the interests of different states overlap. This makes the development of the Arctic and the political management of this territory particularly important, not only for the leadership of the Russian Federation but also for its partners. Within the Arctic lie the territories, continental shelves and exclusive economic zones of the following eight Arctic states: Russia, Canada, the United States, Norway, Denmark, Finland, Sweden and Iceland. The Arctic is divided into five sectors, with the northern borders of the United States, Russia, Canada, Denmark and Norway as the base, the meridians as the sides and the North Pole as the apex. This system has evolved based on a longstanding de facto delineation of the rights and interests of the respective states, recognizing the priority of these countries in exploring and developing different areas of the Arctic. 
The Russian Federation holds about $34 \%$ of the potential Arctic oil reserves, $67 \%$ of the Arctic gas reserves and over $60 \%$ of the gas condensate reserves [1,2]. Additionally, the Russian Arctic zone is home to the largest number of people compared to the other circumpolar states. For the Russian Federation, the Arctic zone is of very high economic and geopolitical importance. In this region there are the following resources: $80 \%$ of the Russian Federation's explored reserves of commercial-grade gas, $40 \%$ of its gold, $60 \%$ of its oil, $90 \%$ of its chrome and manganese, $47 \%$ of its platinum metals and $100 \%$ of its diamonds. Currently, 91\% of the Russian Federation's natural gas, $100 \%$ of its diamonds, $90 \%$ of its nickel and cobalt and $60 \%$ of its copper are being extracted in this zone. The total value of mineral resources in the Russian Arctic is 1.5-2 trillion roubles [3]. The Barents and Kara Seas are considered the richest in the Arctic region. Large offshore fields of natural gas and gas condensate have been explored in the southwestern part of the Kara Sea, near the Yamal Peninsula. The largest of these are the Leningradskoye field (preliminary estimated $\mathrm{ABC} 1+\mathrm{C} 2$ gas reserves exceed 1 trillion cubic meters) and the Rusanovskoye field (780 billion cubic meters). Development of the offshore fields is planned to start after 2025. These data show that for the Russian Federation, the Arctic zone in general and the Arctic continental shelf in particular are of very high economic and geopolitical importance.

At the same time, there are many problems specific to the Arctic zone. First of all, many of these problems are related to the short Arctic season, its fragile environment and its lack of logistical bases. Secondly, there are other problems related to the sectoral sanctions that have been announced by the USA and the European Union, the lack of technology for the development of fields in the Arctic (primarily in water areas mostly covered with ice) and the high cost of production (many offshore gas fields are currently unprofitable). To solve these problems, it is necessary to significantly increase funding for basic and applied oil and gas science to create new technologies for exploration, drilling and the production of hydrocarbons in real time. State authorities in the Russian Federation are taking economic policy measures to develop the Arctic, based on the use of market institutions through the creation of eight support zones for development. The formation of these zones is intended to address a number of challenges, including the holistic and integrated development of the territories and the harmonization of various activities within the framework of the Russian Arctic development strategy. Particular attention should also be paid to in-depth preparation of marketable gas products in the form of liquefied natural gas, synthetic liquid fuels and hydrogen, which are highly sought after on the global market. The introduction of these developments will significantly increase the profitability of Arctic hydrocarbon development.

As noted by numerous experts [4-6], the main key task for the long-term sustainable development of the Russian oil and gas sector is to develop the hydrocarbon potential of the continental shelf. At the same time, such development must, on the one hand, be balanced and, on the other hand, be intensive enough to make the Arctic zone of the Russian Federation the world's largest oil and gas production region $[7,8]$. An important challenge is to develop a commissioning strategy for the Arctic shelf fields that balances raw material extraction, consumption levels, possible demand and the building up of reserves for future generations [1].

The strategic objective of the long-term efficient development of the oil and gas industry in the Russian Arctic should be rational and environmentally safe subsoil use, supported by the introduction of high-tech and digital solutions; the development and testing of advanced Russian equipment and local production and the transfer of global technological solutions that will provide significant cost savings and improve the environmental profile of oil and gas production. Furthermore, the implementation of oil and gas projects in the Arctic should have a social effect. Creation of new jobs and competencies and the development of infrastructure and related industries will make a significant contribution to the socio-economic development of the Arctic regions and the country's economy as a whole $[6,9,10]$. 
The Strategy for the Development of the Arctic Zone of the Russian Federation and National Security for the period up to 2035 (hereinafter referred to as the Strategy) indicates the importance of ensuring the sustainable development of the Russian Arctic. The concept of sustainable development is currently one of the most relevant at the international level [11-15]. In accordance with the Strategy, the urgent tasks in the development of the Russian Arctic are to identify priority areas for scientific and technological development and to step up basic and applied scientific research in the interests of developing the Arctic. In addition, the Strategy envisages the creation and development of a new model for the implementation of economic projects in the Russian Arctic. The Arctic Strategy has a separate section on international cooperation, in which foreign investments play a central role. The government is mainly interested in technology and investment in the energy sector, which is subject to Western sanctions. Western companies can cooperate in infrastructure projects and in solving environmental problems.

A number of works by domestic and foreign scientists are devoted to the issues of increasing the potential of the Russian Arctic. It is noted that sustainable economic growth in the Arctic regions is possible only if the "knowledge-intensive" economy is increased, which determines the need for an active innovation policy in these regions [16,17]. The scientific problem is the lack of a comprehensive methodological approach to the study of the sustainable functioning of industrial systems in the Arctic [18]. A number of authors point out that the assessment of the aggregate technical and economic potential of a field is a key condition for effective strategic management of the oil and gas complex when developing both onshore and offshore hydrocarbon fields in the Arctic [19-21]. A certain number of works by Russian scientists are devoted to the issues surrounding the strategic management of mineral extraction processes in the Arctic [22-25]. Foreign researchers also pay attention to this issue. In particular, works on this topic state that the Russian regulatory framework has created the necessary framework and guidelines for the sustainable development of the Arctic regions, but it is necessary to develop these principles by creating effective legal instruments that establish a sustainable approach to the Russian Arctic [26,27]. The development of a system of indicators for monitoring the state of sustainable development of the Arctic regions is imperative [28,29]. A number of researchers note the need to digitize the processes of economic activity in the Arctic in order to solve the problems of assessing the potential of the Arctic fields [30,31].

It is, however, worth noting that the problems of strategic management are often investigated by specialists without taking into account the specifics of the Arctic regions as well as the complexity of Arctic offshore deposits for research and evaluation. Currently, there is a lack of modern research devoted to the problems of strategic management of the rational use of natural resources in general, and the problems of assessing the potential of deposits in particular.

The subject of this research is to examine the methodological aspects of assessing the technical and economic potential of Arctic fields.

The object of the research is the oil and gas complex of the Arctic regions of the Russian Federation.

The aim of the research is to consider methodologies that can be used in the process of assessing the technical and economic potential of Arctic fields, and to develop these methodologies by forming the author's list of indicators for such an assessment.

The main objectives of this research are as follows:

1. To assess the extent to which the problem of assessing techno-economic potential has been studied;

2. To examine the methodology for assessing the technical and economic potential of hydrocarbon fields in the Arctic;

3. To identify the problems arising in the process of such assessments;

4. To develop the author's list of technical and economic indicators necessary to assess the technical and economic potential of the development of Arctic offshore oil and gas fields. 
In view of the tasks set, this research is relevant, as its main objective is within the framework of the urgent tasks set in the Strategy for Development of the Arctic Zone of the Russian Federation and Ensuring National Security for the Period to 2035 [32].

\section{Materials and Methods}

The theoretical basis of the concept of potential.

We should consider the relationship between the concepts of 'potential', 'resource potential', 'economic potential' and 'techno-economic potential'. It should be said that at present these concepts are mostly studied at the level of an enterprise or region.

Thus, in general, potential is defined as "the totality of available factors of production, intelligence, production reserves and capabilities that can ensure the production of highquality goods necessary to meet the comprehensive needs of various categories of the population of the country" [26]. Additionally, potential is defined as the totality of available means and opportunities in any field.

The potential of a deposit can be defined as the totality of resources that a deposit possesses and the conditions of their most rational use.

At present, economic potential is a category that is intensively studied at the level of an enterprise, region, territory, sphere of activity or country. In general, the economic potential of a business entity is the ability of that business entity to develop the set of resources available to it and to generate the targeted economic performance results [28]. In our opinion, the economic potential of a field should be understood as the totality of economic results from the development of that field.

The technical potential of a field is a set of technical indicators of a given field that characterize the difficulty of its development. Technical potential has a direct impact on economic potential, as economic results may vary in fields with comparable levels of reserves, depending on the conditions of their development.

The elements of the resource potential of an enterprise can be considered as all the resources that are in any way related to the functioning and development of the enterprise. Elements comprising the resource potential of an enterprise include fixed production assets, personnel, technology, energy and information.

Some researchers argue that the concept of "resource potential" is broader in meaning than the concept of "economic potential" [30]. Other researchers regard resource potential as a part of economic potential [31]. In our opinion, we agree that resource potential is part of economic potential, as resource potential reflects the amount of resources and conditions of their use, while economic potential takes into account the indicators of efficiency of the use of such resources.

Currently, a number of works by domestic authors are devoted to technical and economic analysis. Technical and economic analysis is used to determine the efficiency of production $[33,34]$ when selecting options for the implementation of projects in various areas of production $[35,36]$, including the development and justification of field development options [37].

An important and current scientific issue is the assessment of the technical and economic potential of Arctic oil and gas fields. At present, the researchers in this field of knowledge have revealed that both the technical and economic potential of the Arctic oil and gas fields can be comprehensively assessed only with a careful selection and justification of indicators reflecting the specifics of these fields [19]. It is also necessary to note that the issues surrounding the evaluation of the technical and economic potential of these fields are not considered with sufficient intensiveness, which is reflected in the insufficient amount of scientific research on this topic. It can be stated that this sphere is understudied.

At the present time, technical and economic potential is defined as "an aggregated ability of separate oil and gas fields to provide the creation of maximum regional effects and form the maximum efficiency of investment projects under definite conditions of regional development on the base of available technical opportunities" [19]. The regional effects in 
question are understood as "the improvement of the main socio-economic parameters and indicators that form the level of sustainable regional development".

Currently, there is no generally accepted methodology for assessing technical and economic potential in general, as well as the potential of the oil and gas industry in particular.

In general, the methodology for assessing the technical and economic potential of an oil and gas field can be represented by a certain sequence of stages, which is as follows:

1. Selection of indicators reflecting technical potential.

2. Selection of indicators reflecting economic potential.

3. Bringing of qualitative indicators to quantitative expression.

4. Assessment of technical potential by determining the integral indicator.

5. Assessment of economic potential by determining the integral indicator.

6. Assessment of technical and economic potential.

It should be noted that although there is no disagreement on the sequence and content of the stages of the basic algorithm of techno-economic potential assessment, there is a certain variability in the methodology of the implementation of each of the stages. The problems to be solved in carrying out a techno-economic potential assessment can be divided into several blocks (Figure 1).

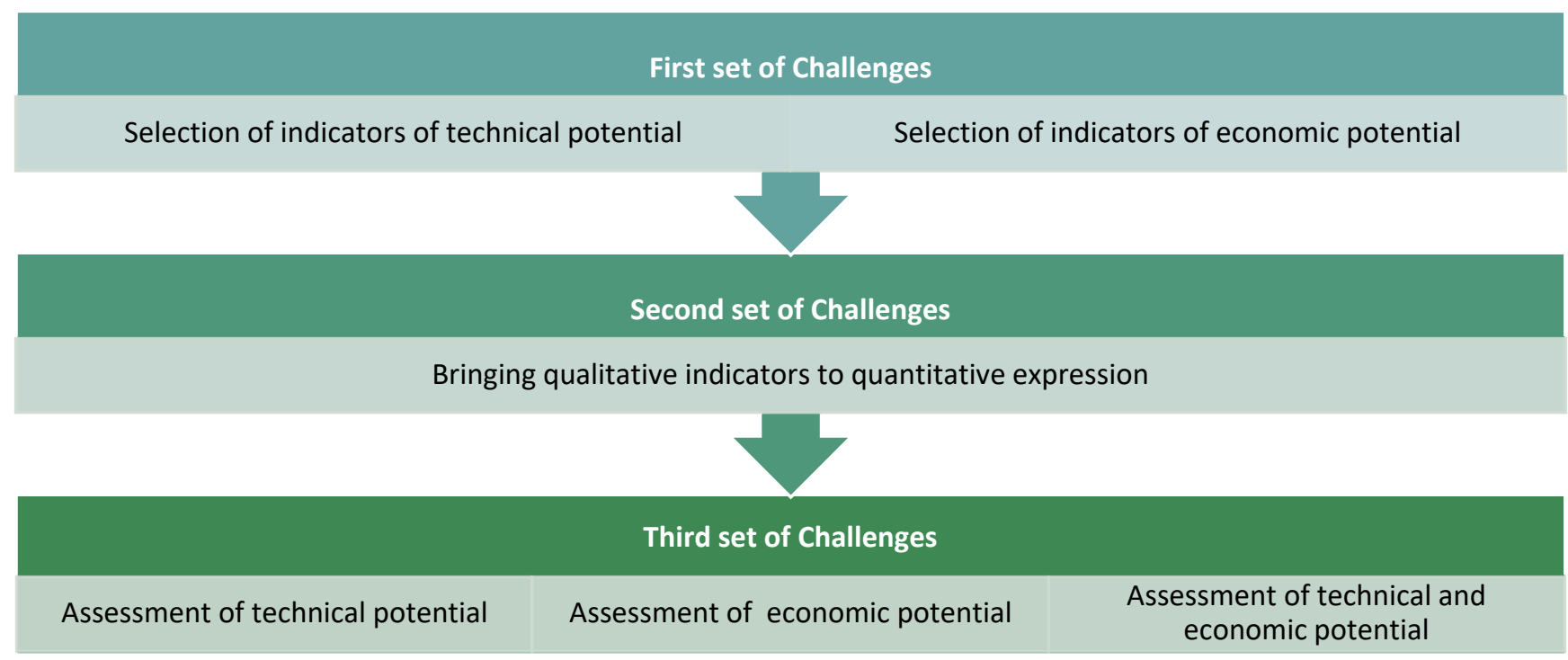

Figure 1. Methodological problems in assessing the technical and economic potential of an oil and gas field.

The first set of challenges arises in the first stages of the algorithm and is related to the choice of indicators reflecting technical and economic potential. Even for the evaluation of similar objects, namely, different fields in the Arctic, the indicators may differ.

The second set of challenges arises in the third stage of the algorithm and is related to the choice of methods for the reduction of qualitative indicators to quantitative ones, as well as the need to reduce all indicators, which may have different dimensionality, to a common dimensionality.

The third set of challenges is related to the choice of methods in assessing aggregate technical and economic potential and assigning a final integral indicator reflecting the level of oil and gas field development to each assessment object (Steps 4-6).

Description of the stages of the assessment of the technical and economic potential of an oil and gas field

Choice of evaluation indicators. Researchers note that "the strategic management of the oil and gas complex should be based on the construction of a system of balanced indicators, taking into account the diverse features of the Arctic fields" [38]. However, the concept of balance is rather subjective. It can be argued that the indicators that are the basis of a balanced system, in the classic view, should reflect the following four strategically im- 
portant areas: financial performance; customer relations; organization of internal business processes and innovation, training and organizational development.

It should also be noted that the choice of indicators used to assess both the economic and technical potential of a field depends on the stage of field development. Thus, Galyautdinov I.M. and Krasnov O.S. [39] suggest taking into account the adapted indicator of net present value as an indicator reflecting the economic potential of an oil field at its late stage of development.

However, the specifics of oil and gas fields in the Arctic are such that it is not sufficient to act only within a balanced scorecard system when assessing their technical and economic potential. The technical and economic potential of these fields can also be assessed by applying a broader list of indicators.

A.M. Fadeev proposes the assessment of the technical and economic potential of a birthplace according to 12 indicators (6 technical and 6 economic) [37]. The list proposed by A.M. Fadeev does not divide the indicators into homogeneous groups reflecting the characteristics of the indicators. It also does not take into account the possibility or impossibility of changing the indicators over time. In our view, in order to better assess the technical and economic potential of the Arctic offshore oil and gas fields, it is necessary to expand the above list of indicators. In particular, among technical indicators, it is necessary to allocate indicators, the values of which are invariable and whose values may change in the course of additional surveys, infrastructure development, etc. Among economic indicators there should be indicators reflecting both the resource potential of a field and factors surrounding investment attractiveness. The list of indicators should also reflect the environmental component, as well as possible revenues for the state from the development of the field.

The need to quantify qualitative indicators.

The need for the fullest possible evaluation of the various indicators raises the problem of their multidimensionality. Indicators such as "market availability", "ice conditions", "availability of infrastructure" and "logistical accessibility" are qualitative. Consequently, qualitative indicators need to be quantified in the assessment process. A way of addressing this problem is to use different scales that allow for scoring qualitative indicators.

The problem that is solved at this stage can be attributed to the field of fuzzy sets, as the result requires the construction of a relationship between qualitative scores, such as desirability, and quantitative values. An effective way of solving such a problem is to use the Harrington desirability function [40], the application of which is recommended as an integral indicator of the effectiveness of scientific and S\&T projects [41].

In our opinion, the normalization method, which includes a wide range of scoring methods, can also be used to address this problem. The format of this article does not permit a detailed review of the scoring normalization methods, as these methods are widely known at present, including those that are applicable to the economic problems of scoring [42-44].

In addition to these methods, to solve the problem of converting qualitative indicators into quantitative ones, an expert method of assigning scores on a five- or ten-point scale, as well as other scales, can be applied. The disadvantages of this method are known to be subjectivity and the need to involve experts with a certain level of knowledge in the field of Arctic fields.

Determination of integral indicators. Fadeev A.M. [37] uses an integral indicator for the purpose of assessing the technical and economic potential of the Arctic deposits, which is determined on the basis of the methodology of V. Pluta. This methodology consists of a number of successive stages [45], which are as follows:

1. Standardization of indicators through the formation of a matrix, the elements of which are the indicators of the technical and economic potential of the enterprise, and the reduction of indicators to a common dimension.

2. Differentiation of indicators into stimulators and destimulators (having, respectively, positive and negative impacts on the level of field development). 
3. Calculation of a distance matrix using Euclid's formula.

4. Calculation of an integral index on the basis of distances calculated at the previous stage.

A disadvantage of Plyuta's methodology is that it is complicated and time-consuming. In addition, the methodology does not take into account the weighting characteristics of the indicators. In our opinion, in addition to the above method, the integral indicator method (Formulae (1) to (3)) can also be used:

$$
\begin{gathered}
I_{i}=\sum_{j=1}^{m} I_{y} \times a_{i j} \\
I_{y}=\frac{q_{i j}}{q_{i j}^{e}} \\
I_{y}=\frac{q_{i j}^{e}}{q_{i j}}
\end{gathered}
$$

where $j=1, \ldots, m$-characteristics of the $i$-th quality indicator;

$q_{i j}, q_{i j}^{e}$-value of the $j$-th characteristic of the $i$-th quality indicator respectively of the assessed and the reference product;

$a_{i j}$-weighting coefficient of the $j$-th characteristic in the $i$-th quality indicator.

The calculation of the index $I_{y}$ is carried out by the Formula (2), if the index is a stimulant, and by the Formula (3), if the index is a destimulant.

This method is used to assess coal deposits according to the values of product quality indicators with heterogeneous dimensions, as well as for other purposes [46,47]. The advantage of this method is its simplicity as compared to V. Pluta's methods, as well as the possibility of taking into account the significance of this indicator for evaluation purposes.

Thus, we can state that there is a certain set of tools for the implementation of each of the stages of the assessment of technical and economic potential.

\section{Results and Discussion}

The study reveals that there is currently no generally accepted methodology for assessing the technical and economic potential of oil and gas fields in the Arctic.

A number of problems arising in the process of techno-economic potential assessment have been identified. These problems are mainly related to the variability of possible actions: in most phases of such an assessment, it is possible to choose several implementation options (Figure 2).

In order to improve the assessment of the technical and economic potential of the Arctic offshore oil and gas fields development, the authors considered the first set of problems, namely, the choice of indicators for assessing the technical and economic potential, and developed an extended list of indicators for such an assessment, including 10 technical and 26 economic indicators.

To characterize the technical and economic potential of various economic objects in scientific practice, a wide list of indicators is used, the priority of which is determined differently by different authors. The most common approach to characterizing economic objects and systems in terms of their economic and technical potential is the analysis of income and expenditure indicators, production indicators, organizational and financial characteristics, etc. However, applying this purely economic and financial approach to assess oil and gas field potential would not provide a complete picture, as a number of different specific indicators reflecting the development of the oil and gas complex, including resource potential, climatic conditions and development of service infrastructure, are not taken into account. 
1. Selection of indicators of technical potential

2. Selection of indicators of economic potential -economic indicators;

-technical indicators;

-balanced scorecard system;

-A system of indicators for assessing fields of a given type.
3. Bringing qualitative indicators to quantitative expression

\section{-point scales;}

-indicator normalisation methods;

- expert methods.
4. Assessment of technical potential

5. Assessment of economic potential
-V. Pluta's methodology;

-index calculation method.

-calculation of the average value.

6. Assessment of technical and economic potential

Figure 2. Multivariate implementation of stages in the assessment of the technical and economic potential of oil and gas fields in the Arctic.

The many challenges companies face in developing Arctic mineral deposits require serious preparation. The harsh climate and permafrost, a lack of developed infrastructure and the complexity of logistics schemes, seasonality of works, special requirements regarding materials and technologies, complex contracting strategies and high costs of mobilization and demobilization of contractors, the need for costly environmental measures-this is just a partial list of the difficulties associated with the development of hydrocarbon resources [48].

The authors propose the following indicators (basic principles of assessment) to assess the technical and economic potential of offshore oil and gas field development in the Arctic:

Technical indicators.

One of the main conditions determining the possibility of involving the Arctic hydrocarbon base into industrial turnover is the technical accessibility of oil and gas fields for exploration and development. The technical accessibility of hydrocarbon objects depends on the following main factors: the first group of factors has a natural and climatic nature, and, as a consequence, is not subject to change; the second group of factors has been divided into geological indicators and technical and infrastructure indicators, which in turn have a variable nature (subject to change, in the process of additional research conducted, during the study of the field).

Climatic and ice conditions are one of the most important factors limiting access to energy resources in the Arctic region. Large seasonal fluctuations and negative average annual temperatures are among the main features of the Arctic climate.

The main features that characterize the natural conditions in the region are stormy periods (September-November) with wave height up to $6 \mathrm{~m}$; heavy ice conditions in winter-spring time (flat ice up to $2.0 \mathrm{~m}$ thick, ice hummocking and compression up to 3 points, ice fields periodically changing direction, formation of stationary ice formations 
(stamukh) with keel depth up to $20 \mathrm{~m}$, powerful ice jams on sea stationary constructions and coast, etc. [49]); icing of surface and underwater structures; frozen ground; multidirectional and strong underwater currents, etc. Such weather conditions require sophisticated technological solutions and high equipment costs, as there is a need to ensure the maximum reliability and environmental friendliness of the work, as well as an acceptable level of safety and working conditions for the operating personnel.

With considerable ice thickness and sea depths greater than $50 \mathrm{~m}$, the arsenal of technological solutions associated with offshore oil and gas field development and, in part, with exploration is limited, as any technological solutions based on the use of jack-up and semi-submersible platforms are virtually inapplicable under severe dynamic stresses caused by the movement of thick ice fields. Certain technological problems are also associated with the development of the shallow part of the shelf (depths less than 5-10 m), where restrictions on the use of gravity platform bases are associated with their transportation to the point of installation, as well as with the organisation of the transport of extracted products. Each of the technical and technological solutions for oil and gas facilities development has its own economic expression, depending on the type of platform or foundation (shore, artificial island, platform on a trussed base or gravity ice-resistant platform, semi-submersible platform, etc.). These facilities vary in both cost and operating costs. The costs of their construction largely predetermine the total investment burden, its dynamics over time and the profitability of the project [50].

A number of indicators are proposed to be classified as Climate-Related Indicators, with an ordinal number $\left(\mathrm{x}_{\mathrm{n}}\right)$ assigned to them:

1. $\mathrm{x}_{1}$-Distance from shoreline, $\mathrm{km}$;

2. $x_{2}$-Sea depth in the area of the field, $m$;

3. $\mathrm{x}_{3}$-Ice conditions.

Geological, Technological and Infrastructural Indicators.

At present, the development of the Arctic is at a very low level. Currently, 23 fields are identified within its boundaries- 4 oil fields, 8 gas fields, 1 oil-gas field, 8 gas-condensate fields and 2 oil-gas-condensate fields. The majority of the discovered fields are referred to as unique and large fields according to the current classification.

Only Prirazlomnoye oil field (where production is performed by means of an iceresistant stationary platform) and Yurkharovskoye gas-condensate field (where production is performed from the shore by horizontal wells) are in commercial development. The remaining fields have been awaiting further exploration and commercial development for a long time. A summary of Russia's largest offshore fields in the Arctic is presented in Table 1.

Table 1. Characteristics of the largest fields of the Russian Arctic shelf. Source: compiled from materials [51].

\begin{tabular}{|c|c|c|c|c|c|}
\hline Field Name & Type of Field & $\begin{array}{c}\text { Reserves Size } \\
\text { Category }\end{array}$ & $\begin{array}{c}\text { Gas Reserves, } \\
\text { Bcm }\end{array}$ & Location, Sea & $\begin{array}{l}\text { Subsoil User } \\
\text { Company }\end{array}$ \\
\hline Leningradskoe & gas condensate & Unique & 3000 & Kara & PJSC Gazprom \\
\hline Rusanovskoye & gas condensate & Unique & 780 & Kara & PJSC Gazprom \\
\hline Kamennomysskoye-Sea & gas & Unique & 535 & Kara & PJSC Gazprom \\
\hline Pobeda & oil and gas & Unique & 499 & Kara & PJSC ROSNEFT \\
\hline Yurkharovskoye & oil and gas condensate & Unique & 460 & Kara & PJSC Novatek \\
\hline Shtokmanovskoye & gas-condensate & Unique & 394 & Barents Sea & PJSC Gazprom \\
\hline Ledovoye & gas-condensate & Unique & 320 & Barents Sea & PJSC Gazprom \\
\hline North Kamennomysskoye & gas-condensate & Unique & 294 & Kara & PJSC Gazprom \\
\hline Dolginskoye & oil & Large & 200 & Pechora & PJSC Gazprom \\
\hline Ludlovskoye & gas & Large & 131 & Barents Sea & PJSC Gazprom \\
\hline
\end{tabular}

The assessment of the oil and gas potential of the Russian Arctic requires considerable revision and adjustment, as the geological and geophysical knowledge of the northern territories and water areas is very low. The hydrocarbon base of the Arctic shelf at the present stage of its study is considered mainly as gas-bearing. Oil accounts for just over $10 \%$ of the total hydrocarbon potential, which exceeds 50 billion tons in terms of liquid 
hydrocarbons. More than a half of oil resources are in the Pechora Sea (54.8\%), with one third in the Kara Sea. Most of the gas resources are in the Kara Sea (60.6\%) and in the Barents Sea (33.3\%) [50].

The allocation of almost all the most attractive offshore licenses between the two largest companies, Gazprom and Rosneft, has initiated two multidirectional processes. On the one hand, the lack of access to the shelf for other Russian and foreign companies should dramatically slow down the process of its geological exploration. On the other hand, however, the need to fulfil license obligations compels both Gazprom and Rosneft to carry out exploration (which at this stage consists mainly of geophysical surveys), if possible in accordance with the license schedule. The Ministry of Natural Resources (MNR) has promised to monitor this strictly.

Most recently, the Minister of Natural Resources and Ecology signed the 'Programme for the Geological Study of Subsoil Areas in the Arctic Zone of the Russian Federation to Form a Prospective Cargo Base of the Northern Sea Route (NSR) for the Period to 2035'. The Programme is divided into the following 2 stages: I stage-2022-2024, and II stage2025-2035. The total volume of federal budget appropriations is 190.995 billion roubles. It is expected that by 2035 the coverage of small-scale geological surveying works in the Arctic zone of the Russian Federation (ASRF) will be 100\%, and not less than $47.5 \%$ (at present it is $33.5 \%$ ). Hydrocarbon resources both onshore and offshore are planned to increase by more than 413 billion tons of conventional fuel in the D1 category (this is the part of the D1 category resources most studied by geological and geophysical surveys). One of the most important points is that by 2035 the share of private investments in hydrocarbon exploration in the Arctic is expected to be 50 per cent of the Russian total [52].

In 2014, two crucial events affected plans for the development of the Arctic shelf: the fall in oil prices (primarily due to the development of shale oil production and the fall in demand in China) and the introduction of sanctions against Russian offshore oil production by the US and countries in the EU. Sectoral services, including in relation to the oil and gas industry, were imposed by the EU, the US and Canada in two stages. The first stage concerned the supply of equipment. It was introduced in late July and early August 2014. The second stage was introduced in September 2014. It extended the sanctions not only to the supply of equipment, but also to the provision of services, information exchange with Russian partners and the participation of Western companies in the most technologically advanced upstream projects.

The US sanctions are tougher than the EU sanctions. They involve licensing the supply to Russia of equipment for deep-sea hydrocarbon extraction beyond 500 feet $(152.4 \mathrm{~m})$, Arctic offshore development and shale oil and gas reserves. The EU sanctions also apply to deepwater production, but do not specify a minimum depth of production. The list of equipment banned by the US for import into Russia is as follows: drilling rigs, horizontal drilling parts, drilling and completion equipment, Arctic offshore equipment, logging equipment, downhole pumps, drilling and casing pipes, hydraulic fracturing software, high-pressure pumps, seismic survey equipment, remotely operated submersibles, compressors, ripping tools, distribution cranes, risers.

The list of equipment banned for import into Russia by the EU includes equipment for offshore projects, deep-water drilling and exploration in the Arctic, as well as equipment for shale projects. The EU list includes pipes used for oil and gas pipelines of various types and sizes, tubing used in oil or gas drilling, drilling tools and pumps for liquids. The EU has, however, introduced a pre-approval regime for the supply of equipment to the Russian Federation. Appropriate approvals will have to be issued by the authorized state authorities of the countries in which the exporting companies are registered.

All of the above equipment is practically not produced in Russia, and some of it has no analogues in countries that have not imposed sanctions against Russia.

An important feature of the Arctic shelf that needs to be taken into account when assessing its economic significance is the transport accessibility of oil and gas facilities. 
Organising the transport of production directly from the production platform (offloading oil or condensate from the platform to tankers-linear or shuttle-and delivering it directly to markets, as in the project to develop the Prirazlomnoye field in the Pechora Sea, liquefying gas directly on the production or nearby processing platform and shipping it directly to LNG). The option of tanker transportation in difficult ice conditions would require the construction of a dedicated fleet of ice-class oil or LNG tankers, which are significantly more technically complex and significantly more expensive than traditional "non-ice" vessels. The fleet of such tankers may number in the dozens, depending on the destination and volume of supply, and will therefore require enormous material and financial resources.

A further option is organising production transportation to the shore using a pipeline system and integrating the offshore transport infrastructure into the existing or newly created onshore transport infrastructure (similar to the Sakhalin projects or the $\mathrm{Ob}$ and Taz Bays development projects on the Kara shelf). This option is also the most realistic for prospective sites in the deepwater part of the Kara Sea shelf.

The option of gas transportation from the fields to the shore, liquefaction onshore and delivery to consumers using the tanker fleet is being implemented by NOVATEK as part of the Yamal-LNG project at the Yuzhno-Tambeyskoye onshore gas field, where Sovcomflot tanker capacities are used as a subcontractor to provide transportation services.

The choice of the best transport option should be made on the basis of technical and economic calculations.

The natural and climatic features of the Arctic entail the adaptation and optimization of technologies and production processes. One example of process optimization in the Arctic fuel and energy complex is the application of field-transport-system-modelling technology, taking into account vessel movements, storage filling and ice channel freezing. Gazprom Neft has used this technology in its management automation project, with the development of the Kapitan system, which currently ensures efficient year-round export of the entire volume of oil produced from the Arctic fields of Novoportovskoye and Prirazlomnoye while reducing specific transportation costs, despite difficult ice conditions (fixed landfast ice more than $2 \mathrm{~m}$ thick in the Gulf of Ob, drifting ice in the Kara Sea). A striking example of the use of alternative solutions is the development of the Snevit Arctic gas condensate field on the Norwegian shelf. This is the first field development project at a significant distance from the shore, where multiphase product is transported along the seabed to the Arctic Melkøya natural gas liquefaction plant [53].

It is worth noting that Russia currently not only has the largest icebreaker fleet but is also the only country with a fleet of nuclear-powered icebreakers, which virtually no complex expedition in the Central Arctic can do without. The backbone of the Russian nuclear icebreaker fleet is the Arktika-type vessel. Six such icebreakers have been built so far, of which two-Yamal and 50 Let Pobedy-are still in service. In the future, Russia wants to introduce brand new types of ice breakers. For example, the nuclear icebreaker fleet will soon be joined by the first vessel of type 22220, whose main difference will be versatility [54].

In order to describe the influence of indicators of variable nature, in terms of the study of the resource base and technologies of field development in the Arctic conditions to assess the technical potential of the field, it is proposed to identify a number of geological and technical and infrastructural indicators, assigning them the conventional ordinal numbers $\mathrm{g}_{\mathrm{n}}$ and $\mathrm{t}_{\mathrm{n}}$, respectively:

Geological indicators:

1. $\mathrm{g}_{1}$-Degree of exploration (amount of exploration carried out);

2. $\mathrm{g}_{2}$-Stage (degree) of field development;

3. $\mathrm{g}_{3}$-Value of hydrocarbon reserves (category of size of recoverable reserves according to classification).

Technical and infrastructure indicators: 
1. $t_{1}$-Accessible technology (exploration, production and operation) - the availability of technology to develop a field;

2. $t_{2}$-Availability of a well-developed coastal service infrastructure;

3. $t_{3}$-Logistical accessibility of the field;

4. $t_{4}$-Availability of sufficient transport base for development (transport vessels, icebreakers, gas pipelines, etc.)

The classification of technical indicators for assessing the technical and economic potential of developing Arctic offshore oil and gas fields is shown in Figure 3.

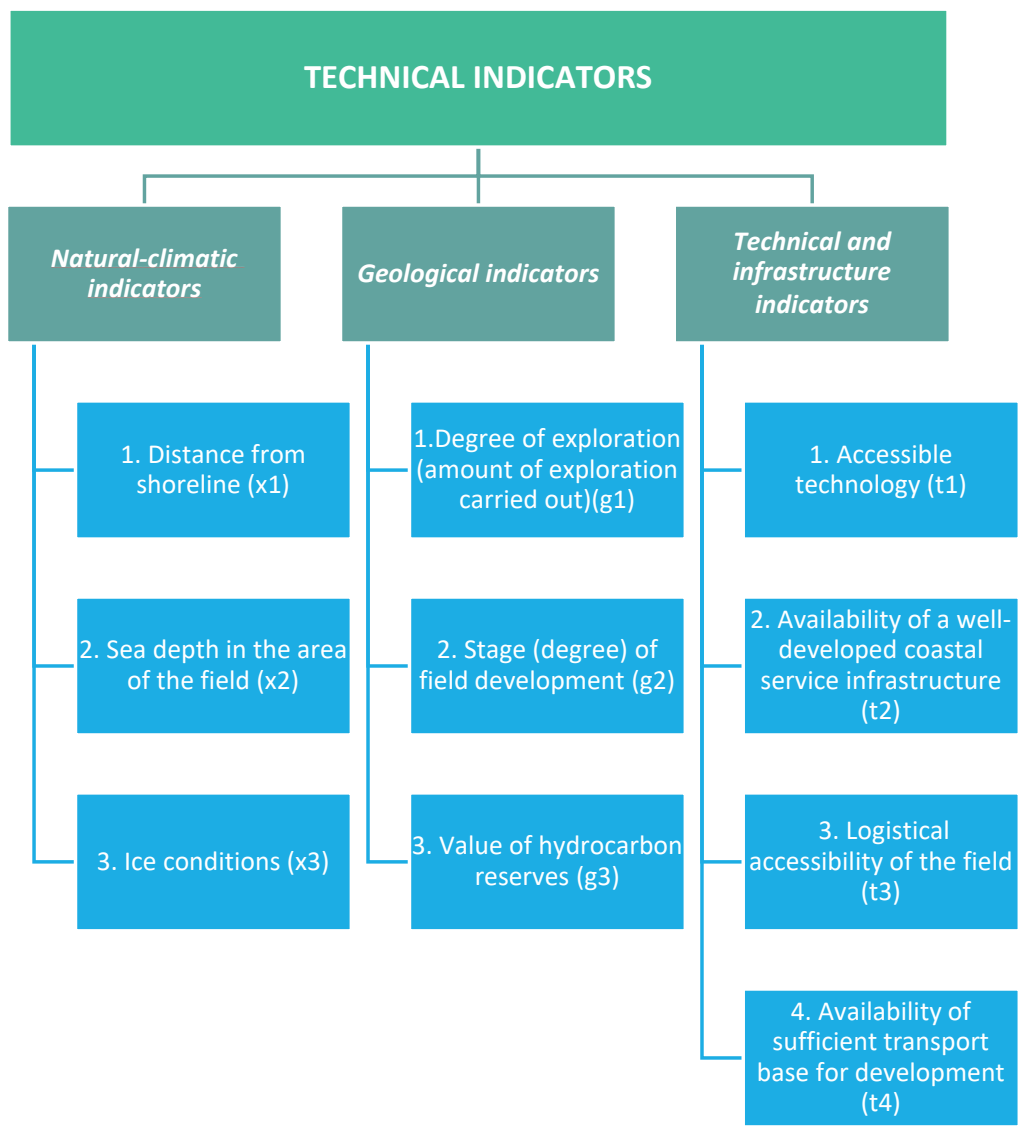

Figure 3. Classification of technical indicators for assessing the technical and economic potential of developing Arctic offshore oil and gas fields. (Compiled by the authors).

The choice of the proposed technical indicators for assessing the technical and economic potential of developing Arctic offshore oil and gas fields is driven by a number of studies in this area. For example, with increasing activity related to oil and gas exploration and production, as well as cargo transportation in the Arctic region, there is a growing need for predicting ice conditions at different temporal and spatial scales [55-57]. Researchers also note the need to study ice accretion on vessels and offshore structures, as this poses a serious hazard, can cause ship instability and overloading of offshore structures and poses a risk to the safety of operations [58]. This is why many studies cover the operation and sustainable development of shipping and port activities on Arctic routes, with several main areas highlighted for further study being the management approach to Arctic transport and logistics challenges, logistics systems for access to Arctic routes, development of large cluster projects in this area and management of specific (ice) vessels [59]. Due to the development of modern technologies of exploration and well drilling, taking into account the peculiarities of geophysical work and technology for obtaining high-quality seismic material in Arctic conditions, all this will increase the development potential and efficiency of offshore oil and gas fields in the Arctic and subarctic shelf [60]. Many researchers, when 
carrying out technical and economic assessments of the project, contributing to the effective and safe development of the field, pay special attention to the development of technologies and methods of development of technically possible and economically feasible solutions for field development, including the construction of infrastructures for pilot operation of the object $[61,62]$. The economic efficiency of implementing measures for the development of offshore fields in the Arctic requires not only a careful choice of modern technologies and technical means but also the development of new technical solutions, taking into account the environmental safety problems of the entire Arctic Ocean [63].

It should be noted that the assessment of the hydrocarbon resource base should take into account the existing or future prospective technical facilities that ensure the availability of oil and gas facilities for deep drilling and subsequent field development. The resource base beyond the technical accessibility zone should be considered as technically unavailable, and its resource potential should be excluded when formulating prospective programs and plans for the development of offshore production projects.

The construction of transport and logistics infrastructure will be one of the main drivers for the development of Russia's Arctic zone when developing hydrocarbon fields, and the next stage will be to increase the transit potential of the Northern Sea Route, as well as the construction of logistics terminals.

Economic indicators.

The economic factor is of crucial importance in justifying the themes and scale of the development of oil and gas resources in the Arctic shelf.

In identifying economic indicators to assess the potential of oil and gas fields, the authors have identified the following three areas: The first is the hydrocarbon resource base, which considers the economic feasibility of field development based on the balance of technically available energy resources and the profitability of their extraction, depending on the market demand for these energy resources. The second is the subsoil user company. In that area we highlight indicators describing the investment attractiveness of the company as well as its technical and environmental experience and capabilities in developing the Arctic fields. The third area is the socio-environmental factor, where indicators characterizing the future level of the socio-economic development of the region are considered, taking into account possible risks and damages to the environment in the region at all stages of oil and gas field development.

Hydrocarbon resource base (resource potential).

Positive prospects for the development of Russian oil production in the Arctic took place during a period of high oil prices-over 100 USD/barrel. Under such conditions, oil production on the Arctic shelf is profitable, but it is possible only with active support from the state (application of tax incentives by the Russian government) and the receipt of funding and technology (equipment, software, management solutions) from Western oil companies with experience in offshore development.

The changes in global energy consumption in recent years present new, much more stringent requirements for a country's hydrocarbon resources, which must ensure its competitiveness in comparison with other energy raw materials and alternative energy sources. Oil and gas in today's realities are gradually losing their status as strategic resources, and their advantage as primary energy sources must be determined primarily by economic factors. The pace and scale of the development of the Arctic shelf depend on the influence of a range of external and internal Russian factors. First of all, clarity is needed on the role of oil and gas as basic energy sources. The situation of the world and domestic energy markets as well as the demand for Arctic oil and gas depend on it. It should be emphasized that the acceptable profitability of large-scale industrial development of the Arctic oil and gas shelf is possible only at high oil and gas prices (for oil USD 80-100/barrel, for gas over USD 350/thousand cubic meters) [50].

In order to describe the impact of hydrocarbon base indicators on the economic potential of a field, it is proposed to identify a number of indicators by assigning them an ordinal number $\left(\mathrm{e}_{\mathrm{n}}\right)$ : 
1. $\mathrm{e}_{1}$-Technically available energy resources, $\mathrm{bcm}$;

2. $\mathrm{e}_{2}$-Projected volume of energy resources production, $\mathrm{bcm}$;

3. $\mathrm{e}_{3}$-Price of energy resources;

4. $\mathrm{e}_{4}$-Share of cost-effective energy resources;

5. $\mathrm{e}_{5}$-Volume of specific capital expenditures;

6. $\mathrm{e}_{6}$-Volume of specific operational costs;

7. $\mathrm{e}_{7}$-Tax burden.

A separate factor affecting the economic performance of offshore projects is the tax system. The tax exemptions introduced for offshore projects have a very significant impact on the resulting estimates, increasing the volume of the profitable resource base. At the same time, state revenues from the involvement of the Arctic hydrocarbon base in industrial turnover are inevitably reduced. If the tax burden increases, the profitability of hydrocarbon objects will decrease and a significant number of them and the corresponding resource base they represent will "flow over" from groups with high economic performance to groups with lower efficiency-including the group of unprofitable ones.

The subsoil user company.

The enormous investments that will be required in the long term to identify, explore and develop Arctic offshore oil and gas fields, as well as to create the associated transport and industrial infrastructure, must be offset by the corresponding oil and gas revenues. It is the major players that are driving the most serious changes in the Arctic region. Small and medium-sized businesses and local administrations simply do not have the necessary financial resources and competencies to manage large projects that would allow for such large-scale investments. This is especially true for extremely capital-intensive and complex projects related to hydrocarbon extraction. Without massive public investment, the development of the Arctic is impossible; private business, even if it involves major resource companies, cannot finance all the infrastructure costs alone.

At present, only state-owned companies with at least 5 years of experience in offshore areas are eligible to develop the Russian Arctic shelf. Alexander Krutikov, Deputy Head of the Ministry for the Development of the East and the Arctic, proposed to allow foreign and private companies to work on the Russian Arctic shelf according to the Norwegian model, i.e., in a consortium with a state-owned operator [64]. The concept of the draft law of the Ministry of Foreign Economic Development on expanding the access of private investors to the implementation of projects on the Arctic and Far Eastern continental shelves provides for the establishment of a state corporation, which will represent the interests of Russia in the consortium of companies. This body will be responsible for mapping offshore unallocated reserves (at present its reserves are 1.1 billion tons of oil and 0.14 trillion cubic meters of gas, or $10 \%$ of the already licensed offshore areas), collecting and analyzing license applications, approving technical field development projects in coordination with the Natural Resources and Energy Ministries, negotiating with investors on establishing consortia, organising electronic auctions and submitting draft decrees to the government on granting licenses to selected investors.

Over the past couple of years, stakeholders in the commodities market have become increasingly focused on environmental, social and corporate compliance (ESG). The terms 'ESG' and 'sustainability' are often used synonymously, especially when it comes to benchmarking and data disclosure. Sustainability is a generic term for many 'green concepts' and corporate responsibility, while ESG has become the preferred term for investors and capital markets. ESG has been proposed as a strategic measure that allows firms to increase profits as well as the amount of attracted investment in company projects, as well as being an indicator of responsibility, corporate reputation and consumer confidence $[65,66]$. Implementing sustainable practices helps firms gain a competitive advantage over industry competitors, increasing productivity and intensity while reducing exposure to systematic risks. ESG practices have been found to reduce firms' downside risk [67], with high (or low) ESG scores indicating low (or high) business risk. 
Energy and oil and gas companies present in the Russian Arctic have already begun to pay more attention to the environmentally and socially responsible development of the region. Some companies are incorporating UN sustainable development goals into their development strategies and are highlighting a set of priority objectives (e.g., Gazprom, NOVATEK and Gazprom Neft). Despite a general recognition of the importance of conditions for sustainable development in the Arctic, many aspects of both the development of Russia's Arctic region as a whole and of the development of the fuel and energy complex in the Arctic remain outside the scope of specific actions [53].

Of those companies active in hydrocarbon production in the Arctic, for example, NOVATEK and Gazprom Neft, the latter is active in the field of ESG. In 2020. The company joined the UN Global Compact, the largest international initiative in the field of sustainable development and corporate social responsibility. In addition, Gazprom Neft took part in the CDP climate rating for the first time and received the highest rating among Russian oil companies. At present, Gazprom Neft is transforming its ESG strategy. Investment funds and banks are restricting investments in hydrocarbon energy and expanding the application of ESG criteria, reflecting environmental and social factors of companies' operations as well as the quality of corporate governance. Gazprom Neft plans to contribute to a fair assessment of the Company's value through timely communication and the provision of complete and reliable information on its operations, as well as the preparation of ESG and investor presentations [68].

The relationship between ESG and the impact on financial performance remains controversial [69]. Many researchers today raise the question of how the consistency of environmental, social and governance (ESG) aspects affects the company's performance, in particular the relationship between ESG performance and economic performance (EP) [70]. Many experts note that ESG indicators are considered to be an important factor of competitiveness of a modern company and have a positive meaning in terms of competitive advantage of the company [71]. However, some researchers say that there is a negative relationship between sustainability performance and the cost of capital [72].

ESG-focused investment is not just a short-term desire to please the public. A company that acts responsibly means that it can serve as a credible investment target. The impact of ESG factors on the value of Russian companies is likely to increase. The more investors and analysts monitor the corporate responsibility of companies, the more important ESG factors will become [73].

We propose a list of indicators used in compiling economic potential in terms of the investment attractiveness of a subsoil user (ordinal number $i_{n}$ ):

1. $\mathrm{i}_{1}$-Return on assets, $\%$ (ROA);

2. $\mathrm{i}_{2}$-Working capital adequacy ratio;

3. $\mathrm{i}_{3}$-Return on equity, $\%$;

4. $\mathrm{i}_{4}$-EBITDA margin;

5. $i_{5}$-Company's strategic stability activity (ESG indicators);

6. $\mathrm{i}_{6}$-Share of state participation in the company.

The following list represents Technical and Environmental Experience (Opportunities) serial number $\left(\mathrm{o}_{\mathrm{n}}\right)$ :

1. $\mathrm{o}_{1}$-Experience in developing Arctic offshore fields (availability of strategic programs);

2. $\mathrm{O}_{2}$-Availability of unique Arctic offshore drilling technologies/or contracts with companies owning unique technologies for offshore field development;

3. $\mathrm{O}_{3}$-Volume of greenhouse gas emissions, in particular $\mathrm{CO}_{2}$;

4. $\mathrm{O}_{4}$-Amount of investment required to capture and bury $\mathrm{CO}_{2}$ (Availability of strategic emission reduction programs);

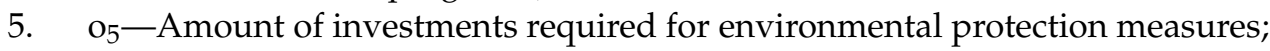

6. $\mathrm{O}_{6}$-Availability of resource-saving technologies. 


\section{Socio-environmental indicators.}

The need to create the conditions for sustainable development is one of the most important tasks for ensuring the sustainable economic and social development of the Arctic territories. For this reason, the strategic management of the oil and gas complex and subsoil use in the Arctic should be interlinked with the level of socio-economic development in the region.

The increased priority of Arctic projects in the overall structure of the Russian economy stimulates interest in the region on the part of major investors. There is a growing trend for business structures to cooperate with one another and to set up joint ventures. The pooling of competences and productive dialogue with the state makes it possible to make positive forecasts regarding an increase in production capacity, the growth of cargo traffic and the formation of modern infrastructure in the Arctic region, in particular in the coastal areas.

For example, as a result of growth in the production capacity of Novatek, which is implementing major LNG projects, the issue of increasing transportation capacity for finished products has become more urgent. In particular, the construction of new shipyards and increasing the number of vessels. Zvezda shipyard is currently involved in largecapacity construction, and the shipyard plans to build 15 gas carriers for the Arctic LNG 2 project. Gazprom Neft is also developing its infrastructure, and plans to launch new ports; it is also studying the possibility of building the Krugly port in the Gulf of Ob. The resource base of this project could be 3.5 billion tons, with a launch date of 2024. The potential annual shipment is up to 20 million tons. Contributions to the regional budget are expected to be RUB 200 billion, and up to RUB 3.5 billion to the federal budget.

Each subsoil user company in the Arctic region, with some degree of sustainability, contributes to the overall sustainability or instability of the region. In order to assess the level of socio-economic development, it is necessary to form such a set of indicators that will comprehensively describe the specific impact of oil and gas fields on regional and national development. For this purpose, we propose to distinguish a number of indicators by assigning them a conventional serial number $\left(\mathrm{s}_{\mathrm{n}}\right)$ :

1. $\mathrm{s}_{1}$-Number of employed, thousand people;

2. $\mathrm{s}_{2}$-Amount of potential investments in the region's infrastructure, million USD;

3. $\mathrm{s}_{2}$-Government revenues from investment, million USD;

4. $\mathrm{s}_{3}$-Budget tax revenues, million USD.

Indicators of Environmental Risks.

When assessing technical and economic potential, the authors propose to include indicators of possible environmental damage as a result of an accidental oil spill in the offshore areas that may occur during exploration and exploratory drilling, pilot operation and field development, in particular the high risk of spills during the transportation of energy resources, due to extremely harsh climatic and ice conditions.

In Arctic conditions, even small spills of oil products can lead to serious negative consequences both for the environment and for the company developing the field. The high risks of oil production and transportation on the Arctic shelf are caused by geographical factors, including the following: requirements for the application of the best available technologies and unique equipment, insufficient levels of infrastructure development and shortcomings in legislation and hydrocarbon transportation schemes.

It is worth noting that with oil spills, the risks extend not only to the operator, but also to suppliers, customers, shareholders, arbitrators and financiers. Economic risks include fines, asset forfeiture, containment and clean-up costs, third-party claims, forced closure and mandatory upgrades, loss of market share, lower share prices, higher finance costs, reduced credit and higher insurance premiums.

When oil products are spilled, the natural environment is polluted, as the ingress of such substances has harmful effects on living organisms, ecological systems and human health. This is the cause of natural (environmental) damage. The expression of such damages in monetary form is called economic damage from environmental pollution [74]. 
When assessing the potential of offshore oil and gas fields in the Arctic, it is necessary to calculate the possible economic damage as a result of an accidental oil spill in offshore areas. For this purpose, it is proposed to single out a number of indicators and assign them a conventional serial number $\left(r_{n}\right)$.

Assessment of the risk of possible damage in the case of:

1. $\mathrm{r}_{1}$-prospecting and exploratory drilling, million USD;

2. $\mathrm{r}_{2}$-pilot exploitation, million USD;

3. $r_{3}$-field development (exploitation and transportation) million USD.

The potential economic impact of an oil spill in the cost estimates for offshore projects can have a significant impact on the technical and economic performance of these projects. It should be noted that, to date, there are no effective technologies for dealing with oil spills or gas releases in ice conditions worldwide.

The classification of economic indicators for assessing the technical and economic potential of developing Arctic offshore oil and gas fields is presented in Appendix A.

In selecting the proposed economic indicators for assessing the technical and economic potential of developing offshore oil and gas fields in the Arctic, the authors have drawn on research that addresses the interaction between the state, extractive companies and society on the strategic sustainability of the Arctic region. The development of mining and other industries is one of the key drivers of economic development in the Arctic. Activities related to hydrocarbon extraction in the Arctic region and on the shelf must be optimized in order to remain profitable in changing market conditions, and to meet growing societal and environmental demands [75]. Particular attention is paid to the potential damage from oil spills to Arctic marine ecosystems [76], as well as to the environmental impacts of offshore produced water discharge [77], which is why oil spill models play a key role as a tool for contingency planning and forecasting during a response [78]. In assessing the technical and economic potential of offshore oil and gas development, environmental and other risks should be assessed both during the construction phase of oil platforms and during their life-cycle management [79-81]. A number of studies point to the development of environmental legislation in the Arctic as a major factor in increasing the region's social and economic well-being [82], and they also highlight the special role of the mining tax system for Arctic offshore projects. [61]. The experience of implementing large-scale projects for the extraction, processing and supply of hydrocarbon fuels, as well as the development of energy and transport infrastructure and the formation of an innovative economy based on high technology, provides new knowledge about the mechanisms of regional development of the Arctic territories, and also takes into account accumulated foreign experience when making decisions in the field of regional Arctic policy [83]. That is why the authors have noted the possibility of allowing foreign companies to work on the Russian Arctic shelf. For example, a total of 37 exploration and production companies operate on the Norwegian shelf, 24 as operators and another 13 as partners in the production licenses [84]. The diversity of companies operating offshore promotes competition and efficiency and provides interest in different types of projects and different types of new and cost-effective technologies. It should be noted that this study has a number of limitations:

1. The article examines examples of Arctic offshore oil and gas fields owned by oil and gas companies in the Russian Federation.

2. In developing technical indicators for assessing the technical and economic potential of offshore oil and gas field development, the authors used the characteristics of the Arctic seas located in the territory of the Russian Federation.

3. The proposed list of indicators to assess the technical and economic potential of offshore oil and gas field development is not universal for all fields of the Arctic shelf. Each offshore oil and gas field in the Arctic is unique in its characteristics, and an individual approach is required each time when assessing the technical and economic potential of a field. 
The results of this study will be used in further research by the authors to assess the technical and economic potential of oil and gas fields in the Arctic, taking into account the developed lists of indicators. The fields of the Arctic shelf will be ranked according to the value of their technical and economic potential, in order to determine the order in which these fields are put into operation. It should be noted that the proposed list of indicators can be modified by the authors in the process of further research; the authors consider adding a number of indicators aimed at achieving sustainable development goals, as well as indicators reflecting the trends of "green energy" development (for example, the use of renewable energy sources in the operation of offshore oil and gas platforms).

The developed list of indicators can be used by the Government of the Russian Federation and other countries to assess the technical and economic potential of offshore oil and gas fields in the Arctic. On the basis of the proposed list, the fields can be ranked according to their technical and economic potential in order to determine the order of in which they are put into operation. As a result of the field ranking work, the efficiency of oil and gas resources development in the Arctic can be increased. The results of the study can help the Government of the Russian Federation to make adjustments to Sections IV and V of the Strategy for Development of the Arctic Zone of the Russian Federation and National Security for the period up to 2035.

It should be noted, however, that some technical indicators can be changed through the efforts of oil and gas companies as well as the government in this area. For example, investment in exploration can change the value of indicator "g1- Degree of reserve exploration". Infrastructure development efforts will change the value of indicator "t2Availability of well-developed onshore service infrastructure". Investment in the construction of offshore vessels may improve the value of indicator "t4- Availability of sufficient transport base for field development".

\section{Conclusions}

The pace and scale of Arctic shelf development depends on the influence of a range of external and internal Russian factors. First of all, clarity is needed on the role of oil and gas as basic energy sources. The situation of the world and domestic energy markets as well as the demand for Arctic oil and gas depend on it.

Large-scale development of oil and gas fields on the Arctic shelf requires the introduction of innovative technologies at all stages of the production process, including prospecting, exploration, field development and the delivery of oil and gas to consumers. The following conclusions are drawn from this research:

1. It has been revealed that the area of assessing the technical and economic potential of a mine site is currently understudied.

2. It has been established that, at present, there is no generally accepted methodology for assessing the technical and economic potential of Arctic offshore oil and gas fields.

3. A number of problems arising in the process of the evaluation of techno-economic potential has been revealed. These problems are mainly connected with the variability of possible actions; when carrying out most of the stages of such an estimation it is possible to choose several options of implementation.

4. This article presents the author's list of technical and economic indicators necessary for assessing the technical and economic potential of developing Arctic offshore oil and gas fields.

Further research will focus on assessing the technical and economic potential of oil and gas fields in the Arctic, taking into account the developed lists of indicators.

The results of this study can be used by the state authorities of the subarctic states to optimize decision-making on the exploitation of Arctic offshore oil and gas fields, and also for the development of strategic programs for the development of various economic sectors in the Arctic. In addition, the developed list of indicators can be used by both Russian and foreign oil and gas companies to form strategies for the development of the company in general and the individual field in particular. The ranking of fields according 
to the value of their technical and economic potential can help various countries develop optimal strategies for the development of Arctic resources, as well as providing a systematic approach to organizing the management of the Arctic zone. In our view, the results of this study can help to develop joint programs for the development of Arctic resources by the Arctic Council member countries, and hence contribute to preserving the Arctic as a zone of peace and cooperation.

Author Contributions: Conceptualization, G.S. and Y.N.V.; methodology, Y.N.V.; validation, G.S., Y.N.V. and O.V.Z.; formal analysis, G.S. and Y.N.V.; investigation, G.S.; resources, Y.N.V.; data curation, Y.N.V. and O.V.Z.; writing-original draft preparation, Y.N.V. and O.V.Z.; writing-review and editing, G.S.; visualization, G.S. and Y.N.V.; supervision, G.S. and Y.N.V.; project administration, G.S.; funding acquisition, G.S. and Y.N.V. All authors have read and agreed to the published version of the manuscript.

Funding: The research was carried out with the financial support of the grant by the President of the Russian Federation for the state support of leading scientific schools of the Russian Federation, the number of the project NSh-2692.2020.5 "Modelling of ecological-balanced and economically sustainable development of hydrocarbon resources of the Arctic".

Institutional Review Board Statement: Not applicable.

Informed Consent Statement: Informed consent was obtained from all subjects involved in the study.

Conflicts of Interest: The authors declare no conflict of interest. 


\section{Appendix A}

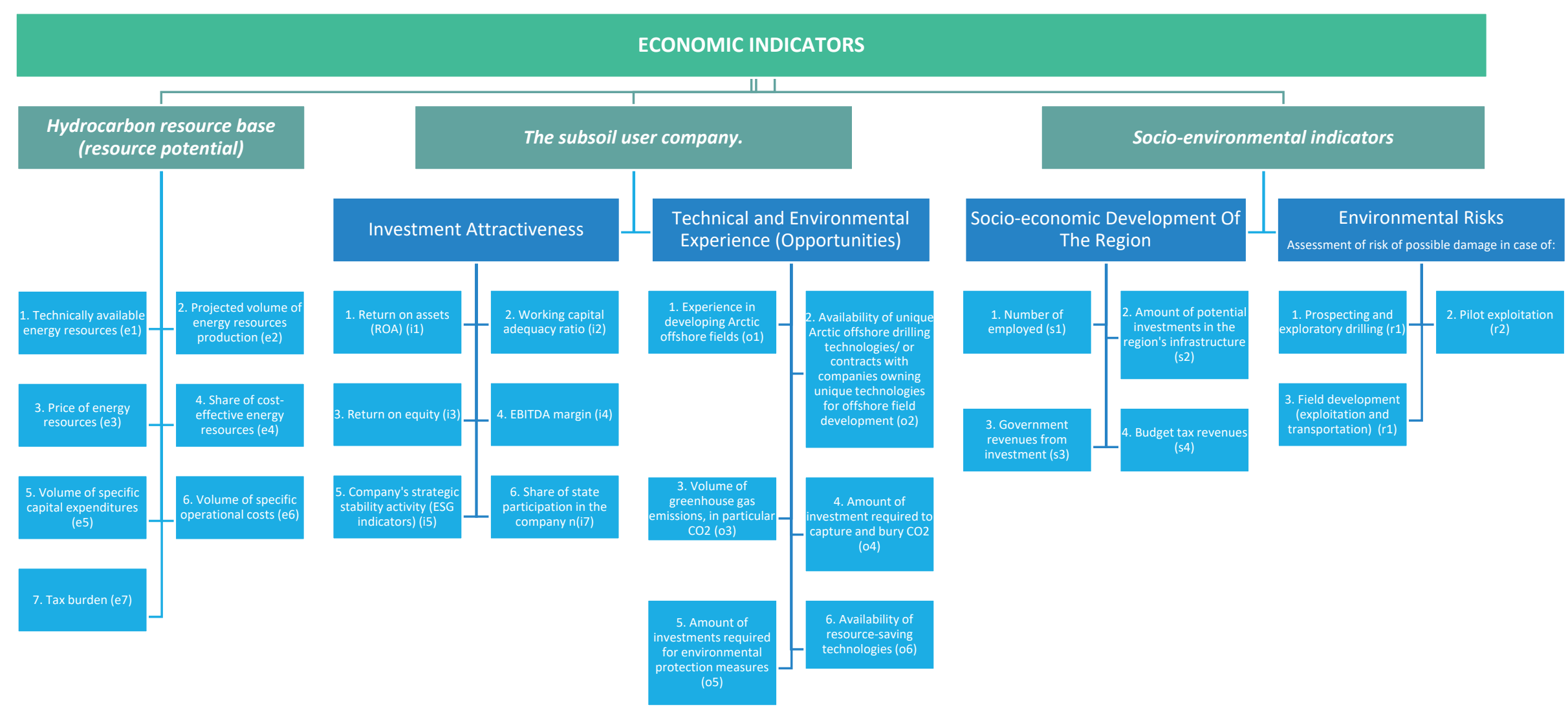

Figure A1. Classification of economic indicators for assessing the technical and economic potential of developing Arctic offshore oil and gas fields (Compiled by the authors). 


\section{References}

1. Safonova, T.Y. Prospects of Russian oil and gas production in the Arctic: From collapse to development. Kreat. Econ. [Creat. Econ.] 2020, 14, 2569-2590. [CrossRef]

2. Kryukov, V.A.; Skufyina, T.P.; Korchak, E.A. Economy of the Modern Arctic: Effective Interaction and Integrated Risk Management as the Basis of Success: A Monograph; KSC RAS: Apatity, Russia, 2020; 245p.

3. Kondratyev, V.B. Mineral Resources and the Future of the Arctic. Gorn. Promyshlenost' [Min. Ind.] 2020, 87-96. [CrossRef]

4. Dmitrieva, D.; Romasheva, N. Sustainable Development of Oil and Gas Potential of the Arctic and Its Shelf Zone: The Role of Innovations. J. Mar. Sci. Eng. 2020, 8, 1003. [CrossRef]

5. Filatova, I.; Nikolaichuk, L.; Zakaev, D.; Ilin, I. Public-Private Partnership as a Tool of Sustainable Development in the Oil-Refining Sector: Russian Case. Sustainability 2021, 13, 5153. [CrossRef]

6. Chanysheva, A.; Ilinova, A. The Future of Russian Arctic Oil and Gas Projects: Problems of Assessing the Prospects. J. Mar. Sci. Eng. 2021, 9, 528. [CrossRef]

7. Fadeev, A.M.; Cherepovitsyn, A.E.; Larichkin, F.D. Strategic Management of the Oil and Gas Complex in the Arctic: Monograph; KSC RAS: Apatity, Russia, 2019; 289p.

8. Skobelev, D.O.; Fedoseev, S.V. Sustainable development and industrial enterprises competitiveness increasing in the Barents Euro-Arctic region. Sever i rynok: Formirovanie ekonomicheskogo poryadka [North Mark.: Form. Econ. Order] 2021, 72, 7-19. [CrossRef]

9. Cherepovitcyn, A.E.; Romasheva, N.V.; Chvileva, T.A. Prospects for the exploration of hydrocarbon deposits in the Arctic based on socio-economic evaluation. Int. J. Civ. Eng. Technol. 2019, 13, 938-948.

10. Kruk, M.N.; Nikulina, A.Y.; Simonchuk, V.D. Corporate Social Responsibility Programs for Arctic Companies to Attract Young People. In Proceedings of the III International Theoretical and Practical Conference "The Crossroads of the North and the East (Methodologies and Practices of Regional Development)", Magadan, Russia, 20-22 November 2019; pp. 114-126. [CrossRef]

11. Draskovic, M.; Delibasic, M.; Jovovic, M. The concept of sustainable regional development-Institutional aspects, policies and prospects. J. Int. Stud. 2017, 10, 255-256. [CrossRef]

12. Manno, J.; Fix, A. Environmental Sustainability and Sustainable Development. In International Studies; Oxford University Press: New York, NY, USA, 2021. [CrossRef]

13. Mondi Group Sustainable Development Report. 2020. Available online: https://www.mondigroup.com/media/13636/mondi group_sustainable_development_report_2020.pdf (accessed on 22 September 2021).

14. Tonelli, F.; Taticchi, P. Industrial Sustainability: Challenges, perspectives, actions. Int. J. Bus. Innov. Res. 2013, 7, 143-163. [CrossRef]

15. Transforming Our World: The 2030 Agenda for Sustainable Development. United Nations Resolution Adopted by the General Assembly on 25 September 2015. Available online: https://www.un.org/ga/search/view_doc.asp?symbol=A/RES/70/1\&Lang=E (accessed on 22 September 2021).

16. Berezikov, S.A. Structural changes and innovation economic development of the Arctic regions of Russia. J. Min. Inst. 2019, 240, 716. [CrossRef]

17. Chvileva, T. Forecasting of Technology Development of the Arctic Hydrocarbon Resources' Extraction. E3S Web Conf. 2020, 162, 01008. [CrossRef]

18. Cherepovitsyn, A.E.; Tcvetkov, P.S.; Evseeva, O.O. Critical analysis of methodological approaches to assessing sustainability of arctic oil and gas projects. J. Min. Inst. 2021, 249, 463-479. [CrossRef]

19. Fadeev, A.M.; Cherepovitsyn, A.E.; Larichkin, F.D.; Fedoseev, S.V. Methods of analysis of the potential hydrocarbon fields in the Russian Arctic. Energeticheskaya Polit. 2018, 34-47. [CrossRef]

20. Cherepovitsyn, A.; Tsvetkova, A.; Komendantova, N. Approaches to Assessing the Strategic Sustainability of High-Risk Offshore Oil and Gas Projects. J. Mar. Sci. Eng. 2020, 8, 995. [CrossRef]

21. Kirsanova, N.; Lenkovets, O.; Hafeez, M. Issue of Accumulation and Redistribution of Oil and Gas Rental Income in the Context of Exhaustible Natural Resources in Arctic Zone of Russian Federation. J. Mar. Sci. Eng. 2020, 8, 1006. [CrossRef]

22. Romasheva, N.V.; Kofi, K.Iv.B. Recommendations for the development of state policy in the development of Arctic oil and gas resources. Econ. Entrep. 2020, 172-176.

23. Nikulina, A.Y.; Kruk, M.N.; Sharok, V.V.; Yakovleva, Y.A.; Simonchuk, V.D. Work in the Arctic: Factors of Successful Adaptation and Corporate Social Responsibility Programs of Extractive Companies; Mediapapir: St. Petersburg, Russia, 2020; 98p.

24. Tabata, S. The Contribution of Natural Resource Producing Sectors to the Economic Development of the Sakha Republic. Sustainability 2021, 13, 10142. [CrossRef]

25. Agarkov, S.A.; Kozlov, A.V.; Fedoseev, S.V.; Teslya, A.B. Main directions of increasing the efficiency of economic activity in the Arctic zone of the Russian Federation. J. Min. Inst. 2018, 230, 209-216. [CrossRef]

26. Gladun, E.; Dressler, H.; von Kamp, H.J. Law and Policy for Sustainable Development of the Russian Arctic; University of Tyumen Publishing House: Tyumen, Russia, 2017; 160p.

27. Marinina, O.A.; Ponomarenko, T.V.; Nevskaya, M.A.; Ochirbat, P. The Analysis of Mining Companies' Corporate Sustainability Assessment Methods (International and Russian Approaches). SHS Web Conf. 2020, 89, 06006. [CrossRef]

28. Nilsson, A.; Larsen, J. Making Regional Sense of Global Sustainable Development Indicators for the Arctic. Sustainability 2020, 12, 1027. [CrossRef] 
29. Vasiltsov, V.S.; Vasiltsova, V.M. Strategic Planning Of Arctic Shelf Development Using Fractal Theory Tools. J. Min. Inst. 2018, 234, 663. [CrossRef]

30. Prieto, A.; Hughes-Cromwick, E. Oil Markets Are Stabilizing, but It's Still an Industry in Decline. 2020. Available online: https: / / www.thirdway.org/blog/oil-markets-are-stabilizing-but-its-still-an-industry-in-decline (accessed on 22 September 2021).

31. Raspotnik, A.; Steinicke, S. The Arctic Institute. The Arctic's Economic Future Is Digital. 2017. Available online: https: //www.thearcticinstitute.org/arctic-economic-future-digital (accessed on 22 September 2021).

32. On the Strategy for Development of the Arctic Zone of the Russian Federation and Ensuring National Security for the Period to 2035. Presidential Decree, No. 645 of October 26, 2020. Available online: https://www.gov.spb.ru/static/writable/ckeditor/ uploads/2020/11/24/01/C\%D1\%82pa\%D1\%82e\%D0\%B3\%D0\%B8\%D1\%8F_Ap \%D0\%BA\%D1\%82\%D0\%B8\%D0\%BAa_2035.pdf (accessed on 1 October 2021).

33. Ryabova, T.F. The Big Dictionary of Commerce; War and Peace: Moscow, Russia, 1996; 399p.

34. Stolyarova, M.A.; Sheptukhina, V.A. Economic Potential: Essence, Structure, Assessment Methods. Innov. Ekon. Prospect. Dev. Improv. 2017, 2, 161-165.

35. Fonotov, A.G. Resource Potential: Planning, Management; Economics: Moscow, Russia, 1985; 151p.

36. Skvortsova, N.K.; Filimonova, L.A. Economic Potential of an Enterprise: Approaches to Evaluation. Mod. Sci. Curr. Probl. Theory Pract. 2020, 77-84. [CrossRef]

37. Fadeev, A.M. Strategic Management of Oil and Gas Complex in the Development of Hydrocarbon Resource Potential of the Arctic: Thesis for the Degree of Doctor of Economics: 08.00.05; KSC RAS: Apatity, Russia, 2018; 425p.

38. Kaplan, R.S.; Norton, D.P. The balanced scorecard-Measures that drive performance. Harv. Bus. Rev. 1992, 70, 71-79.

39. Galyautdinov, I.M.; Krasnov, O.S. Estimation of economic potential of late-stage oil field development projects due to energy efficiency improvement. Oil Gas Geol. Theory Pract. 2016, 11, 4. [CrossRef]

40. Lyubushin, N.P.; Brikach, G.E. Using the Generalized Harrington Desirability Function in Multiparameter Economic Problems. Econ. Anal. Theory Pract. 2014, 18, 2-10.

41. Samokhvalov, Y.Y.; Burba, O.I. Estimation of efficiency of scientific and scientific-technical projects on the basis of generalized Harrington function. Control. Navig. Commun. Syst. 2018, 4, 77-85. [CrossRef]

42. Vedernikov, Y.V.; Garkushev, A.Y.; Karpova, I.L.; Prutkov, G.M.; Suprun, A.F. Normalization of diverse quality indicators of multilevel management complex in view of information security requirements. Probl. Inf. Security. Comput. Syst. 2018, 4, 105-113.

43. Karapetyan, E.A. Using the method of normalization of heterogeneous quality indicators of innovative projects to select the preferred technology of solid waste processing. Hypothesis 2018, 158-163.

44. Bogatyrev, A.A. Normalization of EBITDA Indicator for Company Value Estimation by Comparative Method. Bull. Plekhanov Russ. Univ. Econ. Introd. Path Sci. 2017, 63-70.

45. Plyuta, V. Comparative Multivariate Analysis in Econometric Modelling; Finance and Statistics: Moscow, Russia, 1989; 174p.

46. Vasiliev, Y.N.; Kovalchuk, I.O. Analysis of competitiveness of coal products of enterprises of Russian Federation. In Science and Innovation in Technical Universities: Proceedings of the Tenth All-Russian Forum of Students, Postgraduate Students and Young Scientists; St. Petersburg Polytechnic University of Peter the Great: St. Petersburg, Russia, 2016; pp. 144-145.

47. Ponomarenko, T.V. Methodology of Strategic Competitiveness Assessment of Mining Companies; Polytechnical University Press: St. Petersburg, Russia, 2011; 225p.

48. Energy Centre of the Moscow School of Management SKOLKOVO. Volume 2. Activities of Major Oil and Gas Companies in the Arctic zone of Russia. 2020. Available online: https:/ / energy.skolkovo.ru/downloads/documents/SEneC/Research/ SKOLKOVO_EneC_RU_Arctic_Vol2.pdf (accessed on 1 October 2021).

49. Morgunova, M.O.; Tsunevsky, A.Y. Energy of the Arctic; Bushuyev, V.V., Ed.; IC “Energy": Moscow, Russia, 2012; 84p., Available online: http:/ / www.energystrategy.ru/editions/docs/Arctic.pdf (accessed on 8 October 2021).

50. Nazarov, V.; Krasnov, O.; Medvedeva, L. Arctic petroleum shelf of Russia at the changing period of world energy basis. E'nergeticheskaya politika [Energy Policy] 2021, 7, 70-85. [CrossRef]

51. Russian Federal Geological Fund. Available online: https:/ /rfgf.ru/ (accessed on 8 October 2021).

52. On the New Exploration Programme in the Arctic. SPIEF 2021. Available online: https://www.interfax.ru/russia/770256 (accessed on 15 October 2021).

53. Morgunova, M.; Kovalenko, A. Energy innovation in the Arctic. E'nergeticheskaya politika [Energy Policy] 2021. [CrossRef]

54. Vedmedenko, I. The Entire Russian and USSR Nuclear Icebreaker Fleet in One Infographic. Available online: https://nakedscience.ru/article/tech/ves-sostav-atomnogo-ledokolnogo-flota (accessed on 15 October 2021).

55. Serreze, M.C.; Meier, W.N. The Arctic's Sea Ice Cover: Trends, variability, predictability, and comparisons to the Antarctic. Ann. N. Y. Acad. Sci. 2019, 1436, 36-53. [CrossRef] [PubMed]

56. Graham, R.M.; Cohen, L.; Ritzhaupt, N.; Segger, B.; Graversen, R.G.; Rinke, A.; Walden, V.P.; Granskog, M.A.; Hudson, S.R. Evaluation of six atmospheric reanalyses over Arctic sea ice from winter to early summer. J. Clim. 2019, 32, 4121-4143. [CrossRef]

57. Dai, A.; Luo, D.; Song, M.; Liu, J. Arctic amplification is caused by sea-ice loss under increasing $\mathrm{CO}_{2}$. Nat. Commun. 2019, 10, 121. [CrossRef]

58. Deshpande, S.; Sæterdal, A.; Sundsbø, P. Per-Arne Sea spray icing: The physical process and review of prediction models and winterization techniques. J. Offshore Mech. Arct. Eng. 2021, 143, 061601. [CrossRef] 
59. Lavissière, A.; Sohier, R.; Lavissière, M.C. Transportation systems in the Arctic: A systematic literature review using textometry. Transp. Res. Part A: Policy Pract. 2020, 141, 130-146. [CrossRef]

60. Dziublo, A.; Storozheva, A. Technologies for efficient development of hydrocarbon resources on the Arctic and sub-Arctic shelf of Russia. IOP Conf. Ser. Earth Environ. Sci. 2021, 678, 012001. [CrossRef]

61. Nikitenko, A.A.; Timoshin, I.V.; Bozieva, I.A.; Eremin, Y.S.; Fayzullina, L.T. Assessment of the pilot operation phase impact on the efficiency of the arctic offshore field development from the shore. Neftyanoe Khozyaystvo-Oil Ind. 2021, 2021, 80-84. [CrossRef]

62. Lunkova, L.G.; Melnikov, G.S.; Gulkova, S.G.; Nikitina, A.N.; Gulkov, A.N. The LNG Technology for the Development of the Arctic Gas Fields. IOP Conf. Ser. Earth Environ. Sci. 2021, 720, 012121. [CrossRef]

63. Guseynov, C.S. In Arctic-New technical means and technologies for the development of oil and gas fields in long-term freezing deepwater areas. IOP Conf. Ser. Mater. Sci. Eng. 2020, 734, 012174. [CrossRef]

64. Vadimova, E. Russia's Oil and Gas Industry Is to Be Levelled with Norway. Available online: https://oilcapital.ru/article/ general/27-11-2019/rossiyskiy-neftegaz-podravnyayut-s-norvegiey (accessed on 17 October 2021).

65. Alsayegh, M.F.; Abdul Rahman, R.; Homayoun, S. Corporate Economic, Environmental, and Social Sustainability Performance Transformation through ESG Disclosure. Sustainability 2020, 12, 3910. [CrossRef]

66. Buallay, A. Is sustainability reporting (ESG) associated with performance? Evidence from the European banking sector. Manag. Environ. Qual. Int. J. 2019, 30, 30-98. [CrossRef]

67. Hoepner, A.G.F.; Oikonomou, I.; Sautner, Z.; Starks, L.T.; Zhou, X. ESG Shareholder Engagement and Downside Risk, Working Paper. 2019. Available online: https:/ / ssrn.com/abstract=2874252 (accessed on 17 October 2021).

68. Gazprom-Neft-Sustainable Development. Available online: https://www.gazprom-neft.ru/social/ (accessed on 10 October 2021).

69. Nasrallah, N.; El Khoury, R. Is corporate governance a good predictor of SMEs financial performance? Evidence from developing countries (the case of Lebanon). J. Sustain. Financ. Investig. 2021, 1-31. [CrossRef]

70. Ferrero-Ferrero, I.; Fernández-Izquierdo, M.Á.; Muñoz-Torres, M.J. The Effect of Environmental, Social and Governance Consistency on Economic Results. Sustainability 2016, 8, 1005. [CrossRef]

71. Taliento, M.; Favino, C.; Netti, A. Impact of Environmental, Social, and Governance Information on Economic Performance: Evidence of a Corporate 'Sustainability Advantage' from Europe. Sustainability 2019, 11, 1738. [CrossRef]

72. Gregory, R.P.; Stead, J.G.; Stead, E. The global pricing of environmental, social, and governance (ESG) criteria. J. Sustain. Financ. Investig. 2020, 11, 310-329. [CrossRef]

73. Vostrikova, E.O.; Meshkova, A.P. ESG-criteria in investing: Foreign and domestic experience. Finansovy'j zhurnal (Financ. J.) 2020, 12, 117-129. [CrossRef]

74. Potapov, A.D.; Abramyan, S.G. Economic damage to the environment during reconstruction of linear and extended structures (by the example of main pipelines). MSCU Bull. 2009, 281-283.

75. Tolvanen, A.; Eilu, P.; Juutinen, A.; Kangas, K.; Kivinen, M.; Markovaara-Koivisto, M.; Naskali, A.; Salokannel, V.; Tuulentie, S.; Similä, J. Mining in the Arctic environment-A review from ecological, socioeconomic and legal perspectives. J. Environ. Manag. 2019, 233, 832-844. [CrossRef] [PubMed]

76. Helle, I.; Mäkinen, J.; Nevalainen, M.; Afenyo, M.; Vanhatalo, J. Impacts of Oil Spills on Arctic Marine Ecosystems: A Quantitative and Probabilistic Risk Assessment Perspective. Environ. Sci. Technol. 2020, 54, 2112-2121. [CrossRef]

77. Beyer, J.; Goksøyr, A.; Hjermann, D.Ø.; Klungsøyr, J. Environmental effects of offshore produced water discharges: A review focused on the Norwegian continental shelf. Mar. Environ. Res. 2020, 162, 105155. [CrossRef] [PubMed]

78. Nordam, T.; Beegle-Krause, C.J.; Skancke, J.; Nepstad, R.; Reed, M. Improving oil spill trajectory modelling in the Arctic. Mar. Pollut. Bull. 2019, 140, 65-74. [CrossRef]

79. Derevtsova, K.; Ginevskii, V.; Kataev, G.; Kim, S.; Veselova, P. Ecological risks during offshore construction of oil platforms. E3S Web Conf. 2020, 217, 04002. [CrossRef]

80. Li, J.; Guo, F.; Zheng, M.; Zhang, L.; Wang, F.; Zhai, X.; Duan, M. Risk analysis and management of offshore platforms based on the whole life cycle. In Proceedings of the International Offshore and Polar Engineering Conference, Rhodes, Greece, 20-25 June 2021; pp. 2520-2526.

81. Rahman, M.S.; Khan, F.; Shaikh, A.; Ahmed, S.; Imtiaz, S. Development of risk model for marine logistics support to offshore oil and gas operations in remote and harsh environments. Ocean Eng. 2019, 174, 125-134. [CrossRef]

82. Gladun, E. Sustainable Development of the Russian Arctic: Legal Implications. NISPAcee J. Public Adm. Policy 2019, 12, 29-60. [CrossRef]

83. Shestak, O.; Shcheka, O.L.; Klochkov, Y. Methodological aspects of use of countries experience in determining the directions of the strategic development of the Russian Federation arctic regions. Int. J. Syst. Assur. Eng. Manag. 2020, 11, 44-62. [CrossRef]

84. Ministry of Petroleum and Energy and the Norwegian Petroleum Directorate. Available online: https://www.norskpetroleum. no/en/facts / companies-production-licence (accessed on 1 December 2021). 